\title{
BELPEGTNOSTNI] PROSTRRED]
}

Ing. Michael Hrbata, MPA

Islámský terorismus organizace

Džamá islámíja jako aktuální

hrozba současnosti

Vojenské rozhledy, 2014, roč. 23 (55), č. 1, s. 42-49, ISSN 1210-3292

\section{Islamic Terrorism of Jemaah Islamiyah Organization as a Today's Topical Threat}

\section{Abstrakt:}

Článek pojednává o hrozbě islámského terorismu, o jeho př́činách a motivech, jakož i o jeho původu. Konkrétně je v príspěvku pojednáno o indonéské islamistické organizaci Džamá islámíja (Jemaah Islamiyah), jež je v České republice relativně méně známa. Indonésie, která má největši islámskou populaci na světè, s 202,9 milionu muslimů (88,2 \% obyvatelstva Indonésie), je většinou považována za tolerantni zemi, kde vedle sebe žiji bez větších problémů různá náboženství. Nicméně i zde vyvstala v poslední době hrozba násilného islámského terorismu. Téma je pojednáno $v$ historickém kontextu s přihlédnutím $k$ možným dopadiom na bezpečnostní situaci ve světě.

\section{Abstract:}

This paper refers about the threat of Islamic terrorism, its roots, motives, as well as its origins. Namely the author informs about the Jemaah Islamiyah, Islamic organization, which is less know in the Czech Republic. Indonesia has a larger Muslim population than any other country in the world, with approximately 202.9 million identified as Muslim (88,2\% of Indonesia's population). It is generally regarded as a tolerant country, in which various religions are living side by side without larger problems. Nevertheless even here the danger of violent Islamic terrorism has arisen. The theme is treated in a proper historical context, with regards to possible impacts on security situation in the world.

\section{Klíčová slova:}

Náboženský terorismus, vnitřní bezpečnost státu, militantní islamistické organizace, sebevražedný útok, útoky z 11. záŕí 2001, al-Ká’ida.

Key words:

Religious terrorism, homeland security, militant Islamistic organizations, suicidal attack, the September 11 attacks, or 9/11, al Qaeda. 


\section{Úvod}

V současné době je i přes časový odstup stále diskutovaný dopad terorismu po 11. záŕí 2001 z pohledu politického, národnostního, ale zejména z pohledu náboženského. V průběhu let existovaly nejen v Evropě různé teroristické a militantní skupiny, které byly více či méně orientovány na politický extremismus. Počátkem nového tisíciletí se objevuje pojem islámský terorismus a fundamentalismus.

Cílem tohoto článku je poznání teroristické organizace Džamá islámíja [1] v historickém kontextu dějin Indonésie, jejího vývoje a propojení na další organizace, zejména ty, které působí v místech, kde je v rámci aliančních závazků nasazena i Armáda ČR. V rámci popisného textu využijeme primární a sekundární zdroje vztahující se k teroristickým organizacím, a to zejména psané texty. Je nutné si také v článku přiblížit pojmy, hnutí a organizace, které jsou explicitně známy pouze v souvislosti s Indonésií, tj. Darul Islam, Sarekat Islam, Nadatul Ulama, Masyumi, Gerakan Aceh Merdeka, Muhamadiyah. Dále obecné poznání př́čin a motivů existence těchto organizací, tak jak je popisují např. Marian Brzybohatý, Miroslav Mareš, Jan Novák. [2]

Marian Brzobohatý i Miroslav Mareš ukazují historický koncept teroristických aktivit na místní úrovni, zejména k minimálnímu ovlivnění geopolitického klimatu. Nadále popisují jejich vývoj v současnosti s detailem právě na nově vznikající motivy, tj. náboženské nebo nacionální.

Definování pojmu terorismus je dnes velmi složité právě proto, že definic existuje mnoho. Obecně lze terorismus chápat jako nedemokratické úsilí s cílem o prosazení náboženských, ekonomických, nacionálních, nebo jiných zájmů, za pomocí násilí a zastrašování obyvatelstva. Dnes známe terorismus vedený s cílem získat nezávislost, př́padně terorismus separatistický, jedná-li se o hnutí, která se tímto způsobem pokoušejí osvobodit z koloniálního útlaku, vytvořit nezávislý stát, či se připojit ke státu jinému, než je ten, k němuž patří. Indonésie právě v minulosti, v letech 1942-1950, prošla obdobím emancipace i boje za svou nezávislost. Emancipace nebo terorismus, boj za osvobození nebo jen nezávislost, to jsou témata mladého a nově vznikajícího státu, který byl dlouhá léta kolonií a musel řešit tyto otázky. Text se pokusí též odpovědět na důvody vzniku militantních jednotek operujících proti policii a pravidelné armádě s odkazem na současnost i možná očekávání.

\section{Historické souvislosti}

Indonésie v průběhu minulého století prošla řadou změn. Jednalo o změny politické, náboženské, ekonomické atp. Celkové profilování země bylo velmi obtížné. Indonésie byla ve své historii kolonií Portugalska, Velké Británie, Holandska. Boj za emancipaci Indonésie a vznik nacionalistických hnutí se datuje už na počátek dvacátého století. Problematické období druhé světové války bylo obsazení Indonésie Japonskem. Japonsko dalo, i když omezeně, Indonésii svobodu. Ahmed Sukarno, [3] vlastním jménem Achmed Kusnasosro, spolupracoval s Japonci v ilegálním boji proti Holandsku. V této době již hovoříme o druhé části boje za svobodu a nezávislost Indonésie. Sukarno formálně vyhlásil samostatnost Indonésie, ale této se jí dostalo až v průběhu svobodných voleb $\mathrm{v}$ roce 1949 . V padesátých letech se Indonésie potýkala s vytvořením pluralistického státu 
s přísně odděleným sekulárním systémem. Radikální islámští bojovníci v této době silně usilují a vytvoření islámského státu. Vládě trvá boj mnoho let, než se jí podaří eliminovat tyto aktivity. Při omezení těchto aktivit však musí řešit další problémy, tj. separatistické aktivity směřující k oddělení určitého území od původního státu, a to na Sumatře. Mezi místa, kde dochází k nepokojům, jsou zejména Jáva, ale také Východní Timor. [4] V poslední době spolu s dopady globalizace, zejména volnějšího pohybu osob, tedy i migrantů, dochází k šírení těchto extremistických a teroristických postojů daleko mimo zemi původu - tedy i do zemí východní a střední Asie a dokonce do Evropy.

Indonésie po svém vzniku prodělala velmi dramatický vývoj, její formování procházelo v několika etapách. První etapu můžeme datovat od roku 1950 do záŕí 1965, kdy se Ahmed Sukarno, který v prvopočátku byl u zrodu indonéské demokracie a orientoval se na státy bývalého východního bloku. Provázání na komunistický blok na konci padesátých let minulého století mělo pro Indonésii fatální dopad a předurčilo, že Sukarno vehnal mladou demokracii do rukou totalitárního režimu. V roce 1959 rozpustil Sukarno parlament a o čtvrt roku později se prohlásil doživotním prezidentem.

V polovině šedesátých let dvacátého století proběhly v Indonésií antikomunistické čistky [5] za účasti pravidelné armády. Z tohoto aktu se následně vyprofilloval generál Hadž Mohamed Suharto, který se postavil nejprve do čela protikomunistického tažení a následně donutil prezidenta Sukarna k abdikaci. V té době se již formuje druhá část vývoje Indonésie. Hadž Mohamed Suharto se stal diktátorem od roku 1967 do roku 1998. Reformoval indonéskou ekonomiku a přiklonil ji blíže Západu, ale také zahájil očištění Indonésie od komunismu. [6] V dalším období musel Suharto také řešit regionální nepokoje islámských fundamentalistů, v pozdější době zastavení ekonomického rozmachu, který vyústil v jeho odstoupení. [7] Po roce 1998 nabrala Indonésie opět demokratický směr z autokratického režimu, ale v tomto uvolnění se opět pootevřely dveře pro různé radikální náboženské skupiny. Indonésie není jednolitý segment, ale skládá se ze základní páteře ostrovů a mnoha dalších ostrůvků, které jsou separovány, ale nábožensky jednolité. [8]

Indonésie je z velké části z 88,2 \% obývána osobami s muslimským vyznáním. Není to nový fenomén, ale pochází z dávné historie Indonésie. V Indonésii jsou různá náboženství běžná, nikoliv vzácná, nejčastěji se setkáváme s protestanty, katolíky, hinduisty a buddhisty. Též se setkáme s odlišností mezi tradičním a moderním islámem. Jak bylo již v počátku zmiňováno, některá náboženství jsou geograficky oddělená a je tomu tak i v př́padě muslimů. Jak se zdá, tato nehomogenita nahrává velmi náboženským nepokojům a etnickým nepokojům. Nejčastější střety lze zaznamenat u příslušníků tradičního islámu. Zde se setkáváme s radikálními a fundamentalistickými názory směřující k většímu uplatňování práva šaríja [9] nebo vytvoření nesekulárního státu či teokracie. [10]

\section{Politické strany a hnutí Indonésie}

Je tedy zřejmé, že Indonésie prošla velmi vzrušeným obdobím od koloniálního stavu přes ranou demokracii k diktatuře a následně zpět k demokratickému režimu, kdy můžeme chápat tento vývoj jako „nový počátek“. V této části přiblížíme v konturách historický vývoj několika vybraných organizací, které měly vliv na vývoj tohoto státu. 
Sarekat Dagang Islam (Svaz islámských obchodníků) je organizace, jež vznikla v roce 1912, zakladatelem byl Hadži Samanhudi. Původně jako unie obchodníků. Následně podporovala vzdělávání studentů. Mezi zajímavosti patří, že jedním ze stoupenců hnutí byl Sukarno, pozdější indonéský prezident. Hnutí usilovalo o částečnou nezávislost Indonésie na Holandsku. V rámci tohoto hnutí se profilovala levicová frakce, která později vytvořila Komunistickou stranu Indonésie. V roce 1923 vznikla strana Sarekat Islam (Islámská asociace), za kterou byl v roce 1927 Tjokroaminoto zvolen jako člen lidového shromáždění Volksraad. [11]

Nahdatul Ulama (Vzkř́íšní ulámů) je tradiční sunnitské islámské hnutí, které bylo vytvořeno 31. ledna 1926 Wahabem Chasbullahem jako adekvátní oponent nově vznikajícímu hnutí Muhammadiyah. Uvedené hnutí vzniklo za účelem narovnávání sociálních disparit v rámci Indonésie. V počátcích hnutí se tato náboženská organizace zaměřovala na vzdělávání a pomáhala v sociální oblasti. V šedesátých letech dvacátého století organizace podporovala prezidenta Suharta v jeho boji proti komunistickému režimu, i když později se odklonila a stala se jeho opozicí. V současnosti se jedná o politické uskupení. [12]

Muhammadiyah (Mohamedovi stoupenci) je organizace založená v roce 1912 Ahmadem Dahlanem, za účelem sociálního a náboženského růstu. Tato organizace, její reformní část, dodnes působí v rámci Indonésie. Jedná s o sunnitský islám, [13] směr učení, které tato organizace zastává. Muhammadiyah jako největší autonomní organizace působí spíše na půdě vzdělávání. Založila mnoho vzdělávacích škol, institutů, ale také univerzit. V souvislosti s ní hovoříme o reformním a moderním islámu. [14] V současnosti se jedná o politické uskupení.

Dar-ul Islam (Darul Islam, Obec islámu) je organizace vytvořená v období kolem r. 1942. Jednalo se o náboženský směr, některými autory označován spíše za sektu, která podnítila několik regionální nepokojů s cílem vytvoření islámského státu. Představitelem této skupiny byl Sekarmadji Maridjan Kartosuwirjo, který byl v čele „,indonéské islámské armády“. Ještě před potlačením této skupiny vznikla další křídla Hizballáhu (Hizbullah, Strana boží), a také Džamá islámíja (Jemaah Islamiyah). Tato skupina operovala na západní Jávě, v Ačehu a v jižní Sulewesi. Odhad bojovníků je 15000 osob. Do dnešní doby tato skupina není plně prozkoumána, nebot’ se též předpokládá, že část z veteránů těchto radikálních hnutí se také přenesla do organizace nazvané Komando džihád. Mimo jiné tato skupina proslula plánováním útoku proti prezidentu Sukarnovi.

Gerakan Aceh Merdeka je separatistická organizace, která vznikla v průběhu roku 1976 a existovala do roku 2005. Bojovala za odtržení provincie Ačeh (ang. Aceh) od Indonésie. Vznikla v severní oblasti Sumatry, kde je rozšířen moderní islám s menší komunitou protestantů. Gerakan Aceh Merdeka čerpala v prvopočátcích z nacionalismu a z přiřazení této provincie $\mathrm{k}$ Indonésii po skončení nadvlády Holandska. Později získala provincie Ačeh [15] zvláštní postavení, které jí udělil prezident Suharto.

Ross uvádí, že toto hnutí bylo děleno na tři samostatné části podle období a počtu aktivních členů. Není zřejmé, zda se jednalo o členy, kteří byli registrováni, ale předpokladem je odhad autora. V první části autor uvedl časové rozpětí od 1976 až 1979, kde je odhadován počet aktivních stoupenců od 25-200 osob (oběti cca 100 osob). Druhé období popisuje od roku 1989 až 1991, kde odhad stoupenců je 200 až 750 (počet obětí 2000-10 000). Třetí období je datováno 1999-2002, počet stoupenců 15 000-27 000 (počet obětí 4364). Z těchto číselných údajů je patrný nárůst podpory tohoto hnutí. 
V prvním období útoky směřovaly na ekonomiku v severním Ačehu. Jednalo se o partyzánskou válku, nebot' k otevřenému střetu a vyvolání destabilizace tato hnutí nemělo dostatek sil. Na druhou stranu nacionalistická hnutí měla již zkušenosti obdobných konfliktů od roku 1912, kdy bojovali za vytvoření samostatného státu. Využili své přednosti a znalosti vedení partyzánské války. Druhá část konfliktu byla již více organizována. Členové tohoto uskupení byli také podporováni z části osobami z pravidelné armády a materiální podpora ve formě výcviku, ale i hmotných zdrojů přišla z Libye a Íránu. Druhá etapa povstání byla velmi krutě potlačena. Třetí období, které předcházelo pádu prezidenta Suharta, bylo vedeno linií předchozího konfliktu. Mladí radikálové připomněli potlačení nepokojů z předchozích let a po stažení armády opět vyvolali nepokoje. Tentokrát však byli podporováni z Malajsie, kam se po druhém období stáhli a odkud materiálně zabezpečovali vznikající konflikt. V roce 2005 proběhla jednání, kdy došlo k ukončení konfliktů. [16]

Džamá islámíja (Jemaah Islamiyah) je islámská militantní teroristická organizace založená stoupenci islámské teokracie v jihovýchodní Asii na území Indonésie, Singapuru, Bruneje, Malajsie, Thajska a Filipín. V současné době se však př́islušníci této organizace etablují i v jihovýchodní Asii. K vůdcům patřili Abu Bakar Bašír (Bashir), a Abdullah Sungkar. Abu Bakar Bašír byl Suhartem uvězněn za vytvoření radikální teroristické skupiny Komando džihád (JI). Organizace volně navazuje na původní Dar-ul Islam (Obec islámu) a koncepci vytvoření islámského státu. Bašír získával podporu v Malajsii, Singapuru i na dalších místech jihovýchodní Asie. V polovině osmdesátých let dvacátého století se spojil s mudžahedíny (Mujahideen, Majahideem) z hnutí odporu v Afghánistánu. V této organizaci se profilovali i další známí teroristé. [17] Usáma bin Ládin dokonce hovořil o propojení organizace Džamá islámíja s al-Ká'idou.

Budeme-li chtít vymezit pojem terorismus, je nutno si uvědomit, že se jedná o nelehký úkol. Vymezení tohoto pojmu podléhá dobovým náhledům na legálnost a legitimnost odporu proti vládnoucí elitě, náboženství, sociokulturním a politickým tradicím, právnímu systému apod. Podle českého encyklopedického slovníku je terorismus definován jako: „Strategie boje či metoda hrubého zastrašování politických odpůrců nebo hrozbou násilím nebo užití násilím. Toto slouží k vynucení určitého politického cíle; terčem jsou vojenské, policejní nebo jiné objekty, komunikace, významné hospodářské objekty a civilní obyvatelé.“ [18]

\section{Cíle, motivace a struktura teroristických organizací}

$\mathrm{K}$ projevům terorismu může docházet $\mathrm{z}$ mnoha důvodů, a tedy lze konstatovat, že terorismus jako takový může mít mnoho cílů. Někdy na sebe teroristé chtějí upozornit a hrdě se ke svým činům hlásí, jindy ve snaze snížit rizika volí strategii anonymity. Prof. Oskar Krejčí [19] definuje několik hlavních cílů terorismu:

- Reklamní cíl: Upoutání pozornosti veřejnosti pomocí masmédií. Snaha násilnou akcí dát vědět o existenci a programu teroristické organizace. Mediální prezentace.

- Jednorázový násilný akt: Dosažení konkrétních cílů jako je likvidace určité osoby či osob, zničení konkrétního objektu či objektů. Při snaze vynutit si jednání slouží teroristické akce k zastrašení politické moci nebo nátlaku na politickou moc. 
Někdy k takovýmto akcím dochází z důvodů jako je doplnění vlastní výzbroje či získání financí, propuštění vězňů - jiných teroristů apod. Při tomto taktickém užití násilí se obět'mi útoků často stávají zcela nevinní lidé, nemající absolutně nic společného s př́pravou či prováděním vládní politiky.

- Strategický cíl: Terorismus zde představuje nástroj vedoucí k destabilizaci režimu. Vychází z předpokladu, že teroristické akce vyprovokují státní moc k takovým represím a násilí, jehož výsledkem má být revoluční vzpoura mas. To předpokládají především anarchistické doktrinální koncepce.

- Programové cíle: čtyři hlavní druhy terorismu: revoluční, separatistický, pravicový a náboženský.

Motivace útočníků pak bývá také rozlišná. Podle Mariána Brzybohatého [20]:

1. Ideologie. Je nejnebezpečnější motivací teroristických útoků. Pachatelé jsou téměř výhradně profesionálové. Jde o krajně politickou, rasovou, etnickou nebo náboženskou orientaci.

2. Experiment. Pachatelé touží zpravidla po rozruchu, jsou zvědaví na funkci a zejména účinek zařízení, které při akci použili. Pachatelé jsou většinou mladiství.

3. Vandalismus. Projevuje se až patologická touha ničit vše. Pachatelé jsou nejčastěji mladiství, iniciačním faktorem jsou obvykle alkohol a drogy.

4. Zisk. Při těchto útocích jsou zpravidla využívány únosy. Při této motivaci lze předpokládat napojení na organizovanou trestnou činnost - zločinné spolčení.

5. Afekt. Ojedinělý motiv, je typický pro psychopatické osobnosti. Startovacím mechanismem pro útočníka je neřešitelné zklamání a stres.

6. Získat uznání. Dá se přirovnat k pyromanii. Pachatel umístí na exponované místo výbušný systém, který pak sám odhalí a očekává projevy uznání a vystupuje jako hrdina. Zpravidla nepředpokládá, že jeho čin vyvolává davovou psychózu, zmatek. Důsledkem jsou pak lidské oběti a velké materiální škody.

Chtěli-li bychom pojednat o struktuře teroristické buňky a pravděpodobných fázích její činnosti, je možno konstatovat, že jde o tyto tři typy:

- Malá skupina - obecně se za malou organizaci považuje buňka s počtem od 30 - 50 členů. Řídícím centrem je velitelská sekce. Ta je provázána se zpravodajskou, podpůrnou a militantní údernou sekcí. První dvě sekce jsou ve většině případů bez duplicity, ale úderné sekce mohou být v malé skupině i vícenásobné.

- Střední skupina - zde již hovoříme o vícenásobném velení, kdy velitelská sekce prímo vede střední velitelský stav a tento jednotky nižšího řádu, které mají zpravodajský, podpůrný a úderný význam.

- Velká skupina - Struktura buňky je obdobná, ale nesmíme opomenout tu skutečnost, že velká skupina může být tvořena dalšími skupinami podle různého charakteru, tj. malými i středními, a jednotícím prvkem je ideologie.

Každá taková skupina provádí přípravy na teroristický útok v konkrétních fázích. Můžeme je charakterizovat jako fáze př́pravné, průzkumné a plánovací, fáze zahajovací, tj. přemístění k cíli a zahájení útoku, fáze provedení útoku, fáze ukončení, tj. přeskupení a vyhodnocení. 


\section{Závěr}

Cílem toho př́spěvku je poznání některých islámských teroristických organizací, zejména islámské kongregace Džamá islámíja a jejího historického konceptu, pro provedení predikce dalšího vývoje. Jak bylo zmíněno, tato organizace původně působila zejména v jihovýchodní Asii. Vycházela z koncepce radikálního fundamentalismu a práva šaría. Působení a propojení této organizace na jiná militantní uskupení (jmenovitě al-Ká'idu) v rámci kooperace a boje proti stejnému nepř́teli dávají této organizaci - i když částečně utlumené policií - velký potenciál. Místa potencionální destabilizace lze najít v Indii, tak i v Afghánistánu, nebot’ již v minulosti byly využity militantními skupinami v boji proti sovětské okupaci. Tam, kde nelze vést válku jiným než konvenčním způsobem, se setkáme s radikálními skupinami. Tyto skupiny nemají velkou podporu obyvatelstva a ani nedokáží efektivně dlouhodobě držet získaný prostor, ale velmi významně působí na psychiku protivníka. Jejich schopnost donutit ke spolupráci část obyvatel pod pohrůžkou násilí nebo únosu, tedy kriminálním činem, je vysoká, avšak je to i slabé místo těchto organizací. Další výhodou, kterou si tyto organizace uvědomují, je „maskování“. Dlouhodobá nečinnost a aktivace až v době, kdy je získáno dostatečné množství informací pro provedení útoku.

Závěrem je možné zkonstatovat, že neexistuje pravidlo nebo doporučení jak se účinně těmto organizacím v současnosti bránit. Neexistuje žádné univerzální pravidlo ani doporučení, avšak pokud bude prováděna důsledná analýza všech sociálních motivů a porovnání s historickým konceptem a v rámci geopolitického schématu, budeme schopni aspoň s menší mírou pravděpodobnosti předpovídat rizikové lokality.

\section{Poznámky k textu:}

[1] Džamá islámíja (arabsky al-džamá'atu 'l-islámíjatu, ang. Jemaah Islamiyah, česky Muslimské společenství) je teroristická organizace spolupracující s teroristickou sítí al-Ká'ida. Bojuje za vytvoření islámského státu na území jižního Thajska, Malajsie, Indonésie a jižních Filipín. Mediálně patrně nejznámějším vůdcem skupiny Džamá islámíja byl Malajec Noordin Top, zabit při policejní razii na Jávě v roce 2009. Tento terorista se přihlásil k odpovědnosti za pumové útoky na restaurace na indonéském ostrově Bali v roce 2005, s bilancí 20 obětí. Noordin byl rovněž obviňován z vůdčí úlohy v dalších atentátech na Bali. Ty v roce 2002 připravily o život 202 lidí, převážně australských turistů. Připisují se mu také útoky v letech 2003-2004, jež si v indonéské metropoli Jakartě vyžádaly přes 20 mrtvých. Dostupné na http://cs.wikipedia.org/wiki/D\%C5\%BEam\%C3\%A1_isl\%C3\%A1m\%C3\%ADja.

[2] BRZYBOHATÝ, Marian. Terorismus I a II - Police History. Praha: [s.n.], 1999. 2 sv. (141, 197 s.); MAREŠ, Miroslav. Mezinárodní terorismus v historické perspektivě. In Mezinárodní terorismus: nový nebo starý fenomén. Vyd. 1. Praha: Centrum pro ekonomiku a politiku, 2004. s. 37-50. ISBN 80-86547-33-7; NOVÁK, Jan. Islámský terorismus - Jemaah Islamíyah. In Politický extremismus a terorismus jako ohroženi vnitřni bezpečnosti státu, SVOBODA, Ivo a kol. Brno: Univerzita obrany, 2011, s. 104-112. ISBN 978-80-7231-769-1.

[3] Ahmed Sukarno (1901-1970), první prezident Indonéské republiky (1945-1968), který vedl neúspěšnou válku s Malajsií o severní Kalimantan; navázal dobré vztahy s komunistickými zeměmi (mimo jiné i s Československem); na konec dovedl svou zemi do ekonomické a politické krize a byl následně roku 1965 svržen generálem Suhartem.

[4] ZBOŘIL, Z. - DUBOVSKÁ, Z. - PETRŮ, T. Dějiny Indonésie. Praha: [s.n.], 2005. 578 s. ISBN 80-7106-457-2.

[5] V noci ze 30. záŕí na 1. října 1965 se pokusili komunisté o převrat. Jejich ozbrojená komanda, která se nazvala Hnutí 30. záŕí, napadla velitelskou elitu indonéské armády. Bylo zavražděno šest generálů a mnoho dalších důstojníků. Jeden z mála generálů kteří přežili - Suharto - však dokázal vojenské síly 
zorganizovat a následující den získal kontrolu nad hlavním městem země zpět. Po nezdařeném puči začalo masové zatýkání. Jejich likvidace se zúčastnily téměř všechny vrstvy obyvatelstva. Střízlivý odhad je, že bylo zabito asi 500000 komunistů, zbytek skončil ve vězení. Likvidace agresivního komunismu ve velkém stylu: Indonésie 1965-1966, dostupné na http://www.diskuteri.eu/clanek/likvidaceagresivniho-komunismu-ve-velkem-stylu-indonesie-1965-1966-1126-hwx.

[6] ZBOŘIL, Zdeněk. Suharto - odchod generála, prezidenta a zemského správce. Cevrorevue [online]. 2008, roč. 2008, č. 2 [cit. 2010-01-01]. Dostupný z www: <http://www.cevro.cz/cs/cevrorevue/aktualnicislo-on-line/2008/2/199327-suharto-odchod-generala-prezidenta-zemskeho.html>.

[7] President Suharto resigns [online]. BBC News , 1.1.2010 [cit. 2010-01-01]. Dostupný z www: <http:// news.bbc.co.uk/2/hi/events/indonesia/latest news/97848.stm>.

[8] Srov.: Bali - hinduisté, Flores - katolíci atp.

[9] Šaría je muslimské právo či přesněji komplexní společenské uspořádání, kdy se společnost řídí doslovným výkladem koránu a muslimské tradice. Podle tohoto práva jsou jinověrci bráni jako trpění občané druhé kategorie, jakákoliv misie mezi muslimy je přísně zapovězena, konverze od islámu je trestána. Dostupné na http://aktualityhvezd.wordpress.com/2010/11/29/nabozenske-pomery-v-indonesii-2-islam/.

[10] Teokracie - forma vlády, která se odvolává na náboženskou moc a božské právo.

[11] HOLT, M. - LAMBTON, A. - LEWIS, B. The Cambridge History of Islam. [s.1.]: [s.n.], 1977. s. $191-192$. ISBN 05-2129-137-2.

[12] RICKLEFS, Marle. A History of Modern Indonesia, ca. 1300 to the Present. Stanford: [s.n.], 2001. 369 s.

[13] Zjednodušeně lze říci, že rozdíl mezi sunnity a šíity je více politický než věroučný. Jejich konflikt se táhne od dob, kdy muslimové začali řešit, kdo má vést jejich společenství po Mohamedově smrti. Většina preferovala, že nástupce má být zvolen, menšina, že vůdcovství musí zůstat v Mohamedově rodině. $Z$ větší skupiny vzešli sunnité, z menší šíité. K sunnitům se hlásí výrazná většina muslimů světa, šíité představují většinu pouze v Íránu a Iráku. Dostupné na http://viah.wargaming.cz/clanky/ udalosti/indonesie1.htm.

[14] Viz http://www.muhammadiyah.or.id/ [online]. c2009 [cit. 2009-12-26]. Dostupné z www: <http://www. muhammadiyah.or.id/index.php?option=com_content\&task=blogcategory\&id=208\&Itemid=269>.

[15] Ačeh, ang. Aceh (oficiálně Nanggroë Aceh Darussalam) je autonomní oblastí Indonésie ležící v severním cípu ostrova Sumatra. Na ploše 51937 km² zde žijí více než čtyř miliony obyvatel. Ačeh byl prvním státem v jihovýchodní Asii, který přijal islám. Ačeh má velké zásoby nerostných surovin včetně ropy a zemního plynu. Zásoby zemního plynu v Ačehu jsou možná největší na světě. Dostupné na www: <http://www.cs.wikipedia.org/wiki/Aceh.

[16] ROSS, Michael. Resources Rebellion in Aceh: Indonesia. [s.1.]: The World bank, 2007. s. 35-58.

[17] Na pŕíklad Azahari Usin, Abu Dujana, Jack Roche, Zarkasih atd.

[18] Ottova všeobecná encyklopedie: $M$-A. Praha: [s.n.], 2003. 2 svazek. 509 s. ISBN 80-7181-959-X.

[19] KREJČÍ, Oskar. Mezinárodní terorismus. Mezinárodní politika. 1996, roč. 20, č. 11. s. 19-21.

[20] BRZYBOHATÝ, Marian. Terorismus I. a II.: Police History. Praha: [s.n.], 1999. 62-63 s. ISBN 80-902670-1-7.

\section{Hlavní použitá literatura:}

BRZYBOHATÝ, Marian. Terorismus I a II: Police History. Praha: [s.n.], 1999. 2 sv.

HOLT, Malcolm, LAMBTON, Ann, LEWIS, Bernard. The Cambridge History of Islam. [s.1.]: [s.n.], 1977, ISBN 05-2129-137-2.

KREJČÍ, Oskar. Mezinárodní terorismus. Mezinárodní politika. 1996, roč. 20, č. 11.

MAREŠ, Miroslav. Mezinárodní terorismus v historické perspektivě. In Mezinárodni terorismus - nový, nebo starý fenomén? Vyd. 1. Praha: Centrum pro ekonomiku a politiku, 2004, ISBN 80-86547-33-7.

NOVÁK, Jan. Islámský terorismus - Jemaah Islamiyah. In Politický extremismus a terorismus jako ohrožení vnitřní bezpečnosti státu. Svoboda, Ivo. a kol. Brno: Univerzita obrany, 2011, s. 104-112, ISBN 978-80-7231-769-1.

RICKLEFS, Marle. A History of Modern Indonesia, ca. 1300 to the Present. Stanford: [s.n.], 2001.

ROSS, Michael. Resources and Rebellion in Aceh: Indonesia. [s.1.]: The World bank, 2007.

ZBOŘIL, Z.- DUBOVSKÁ, Z. - PETRŮ, T. Dějiny Indonésie. Praha: [s.n.], 2005. ISBN 80-7106-457-2.

ZBOŘIL, Zdeněk. Suharto: odchod generála, prezidenta a zemského správce. Cevrorevue [online]. 2008, roč. 2008, č. 2 [cit. 2010-01-01]. Dostupný z www: <http://www.cevro.cz/cs/cevrorevue/aktualni-cisloon-line/2008/2/199327-suharto-odchod-generala-prezidenta-zemskeho.html $>$. 